\title{
Effect of Autoclaving and Irradiation on Microbiological Safety and Quality of Ready-to-Eat Bulgogi
}

\author{
Jin-Gyu Park ${ }^{1,2}$, Beom-Seok Song ${ }^{1}$, Jae-Hun Kim¹, Jae-Nam Park¹, In-Jun Han ${ }^{1}$, Han-Joon Hwang ${ }^{2}$, \\ Myung-Woo Byun ${ }^{3}$, Hong-Yon Cho², Young-Wan Kim², Jae-Hyung Mah², and Ju-Woon Lee ${ }^{1, *}$ \\ ${ }^{I}$ Team for Radiation Food Science and Biotechnology, Korea Atomic Energy Research Institute, Jeongeup 580-185, Korea \\ ${ }^{2}$ Department of Food and Biotechnology, Korea University, Jochiwon 339-700, Korea \\ ${ }^{3}$ Department of Food Science and Biotechnology, Woosong University, Daejeon 300-718, Korea
}

\begin{abstract}
This study compared the effects of autoclaving (AC; $121^{\circ} \mathrm{C}$ for $15 \mathrm{~min}$ ), gamma (GR), and electron beam irradiation (EB; 0-20 kGy) on the microbial, physicochemical, and sensory properties of ready-to-eat bulgogi during storage at $35^{\circ} \mathrm{C}$ for 90 d. No viable cells were observed $(p<0.05)$ upon AC, GR or EB at more than $15 \mathrm{kGy}$. However, adverse effects such as tenderization and deterioration of sensory properties were induced in bulgogi upon AC and high dose irradiation. Especially, the hardness and sensory qualities (texture and taste) of the AC-treated samples were extremely deteriorated $(p<0.05)$. These results indicate that use of GR and EB ( $15 \mathrm{kGy})$ can ensure the microbial safety of bulgogi without compromising the hardness and sensory properties (texture, taste and flavor).
\end{abstract}

Key words: bulgogi, autoclaving, irradiation, hardness, sensory property

\section{Introduction}

Bulgogi is one of the most popular Korean traditional meat products with a 1,500 year history, and it has become gradually popular worldwide. Thin slices of beef (sirloin or tenderloin) are marinated in the sauce formulated with soy sauce, onion, garlic, sesame and other seasonings, and cooked over a hot charcoal grill or pan before consumption. Because of rapid industrialization, home-preparation has been changed to commercial readyto-cook/ready-to-eat products. It has been reported that, however, raw beef, soy sauce and raw vegetables may introduce spoilage bacteria into the foods (Beuchat, 1996; Nguyen-the and Carlin, 1994). Song et al. (2001) reported that initial level of Bacillus spp. of soy sauce, which is a major ingredient of bulgogi sauce, were $10^{5} \mathrm{CFU} / \mathrm{g}$. Therefore, a decontamination technology is necessary to preserve the quality of bulgogi during long storage periods under the extreme environments.

Chilled storage $\left(2-8^{\circ} \mathrm{C}\right)$ is generally used to maintain

*Corresponding author: Ju-Woon Lee, Team for Radiation Food Science and Biotechnology, Advanced Radiation Technology Institute, Korea Atomic Energy Research Institute, Jeongeup 580-185, Korea. Tel: 82-63-570-3204, Fax: 82-63-570-3207, E-mail: sjwlee@kaeri.re.kr the quality of bulgogi. A little studies have been conducted to extend the shelf-life of ready-to-cook bulgogi by using antimicrobial effect of medicinal herbs (Park et al., 2005) and low-dose irradiation ( $<10 \mathrm{kGy}$ ) (Jo et al., 2003a). Some commercialized bulgogi sauce is produced after high heat treatment in Korea in order to meet the consumers' hygienic quality standard (Jo et al., 2003b; Lee et al., 2001). However, the heat treatment may adversely affect flavor of the sauce because of losing freshness of vegetables and fruits, resulting in decreased consumers' acceptance (Jo et al., 2003b). In previous studies, the spoilage of ready-to-cook bulgogi could be retarded by heat treatment and low dose irradiation $(<10 \mathrm{kGy})$, but growth of microorganisms in bulgogi was still observed during long-term storage. Thus, higher doses ( $\geq 10 \mathrm{kGy})$ are necessary for significant decrease of bacterial populations in foods such as the foods for immuno-compromised patients. South Africa allows use of irradiation at more than $45 \mathrm{kGy}$ on meat products, and considerable quantities of such products have been sold in recent years (WHO, 1999).

The objective of this study was to compare the effects of autoclave (AC; $121^{\circ} \mathrm{C}$ for $15 \mathrm{~min}$ ), gamma (GR) and electron beam irradiation (EB; 0-20 kGy) on microbial safety, physicochemical and sensory properties of ready-to-eat 
bulgogi (RTE bulgogi) during storage at $35^{\circ} \mathrm{C}$ for $90 \mathrm{~d}$.

\section{Materials and Methods}

\section{Materials}

Korean beef (tenderloin), soy sauce, sugar, onion, celery, green onion, garlic, ginger, whole black pepper, and whole dried red pepper were purchased from local store. The tenderloin from three Korean beeves was obtained after $25 \mathrm{~h}$ of slaughter, and cut into slices $(2 \times 2 \times 0.8 \mathrm{~cm})$ with a knife.

\section{Preparation of bulgogi}

Bulgogi sauce was prepared with ingredients listed in Table 1. Soy sauce and other spices were mixed in a pot and boiled at $100^{\circ} \mathrm{C}$ for $30 \mathrm{~min}$, and the sauce was then cooled to room temperature. Beef slices $(2 \times 2 \times 0.8 \mathrm{~cm})$ were marinated in each prepared sauce by a $1: 1$ ratio for $2 \mathrm{~h}$ in a refrigerator $\left(4^{\circ} \mathrm{C}\right)$ and then cooked. For cooking, the marinated beef was placed on a preheated pan up to about $170^{\circ} \mathrm{C}$, cooked for about $9 \mathrm{~min}$ to have $78^{\circ} \mathrm{C}$ of the meat temperature, followed by cooling for $20 \mathrm{~min}$ at room temperature. The $100 \mathrm{~g}$ of bulgogi were individually placed into an aluminium-laminated low-density polyethylene (Al-LDPE, Sunkyung Co., Ltd., Seoul, Korea). Al-LDPE has the physical properties that water and gas were not transmittable, and melting point and density were $120^{\circ} \mathrm{C}$ and $0.92 \mathrm{~g} / \mathrm{cm}^{3}$, respectively. Each sample was packaged under the vacuum condition $(300 \mathrm{~mm} \mathrm{Hg}$ ).

\section{Autoclaving and irradiation of bulgogi}

Vacuum packaged bulgogi samples were i) not treated (Control), ii) autoclaved at $121^{\circ} \mathrm{C}$ for $15 \mathrm{~min}$ (AC) in HG50 autoclave (Hirayama Manufacturing Co., Kasukabeshi, Japan), iii) gamma irradiated (GR) or iv) electron beam irradiated (EB) at $0,5,10,15$, and $20 \mathrm{kGy}$. For GR

Table 1. Various ingredients contained in bulgogi sauce

\begin{tabular}{lr}
\hline \hline Raw materials & Ratio (\%) \\
\hline Soy sauce & 29.5 \\
Water & 29.5 \\
Sugar & 20.5 \\
Onion & 7.2 \\
Celery & 2.9 \\
Green onion & 5.8 \\
Garlic & 2.9 \\
Ginger & 0.8 \\
Black pepper & 0.1 \\
Whole dried red pepper & 0.8 \\
Sum & 100.0 \\
\hline
\end{tabular}

and EB treatments of samples, one side of the bulgogi samples were gamma-irradiated at $0,5,10,15$, and 20 $\mathrm{kGy}$, and both sides of sample were EB-irradiated at same doses as GR. GR irradiation was conducted using a cobalt60 irradiator (point source AECL, IR-79, MDS Nordion International Co., Ltd., Ottawa, Ontario, Canada) in Korea Atomic Energy Research Institute (Jeoung-eup, Korea). The source strength was approximately $300 \mathrm{kCi}$ with a dose rate of $10 \mathrm{kGy} / \mathrm{h}$. Dosimetry was conducted using $5-\mathrm{mm}$ diameter alanine dosimeters (Bruker Instruments, Rheinstetten, Germany). EB irradiation was performed with an ELV-4 Electron-Beam-Accelerator $(2.5 \mathrm{MeV})$ at the EB-Tech (EBTech Co., Daejeon, Korea). After each sterilizing treatment, the samples were stored at $35^{\circ} \mathrm{C}$ for $90 \mathrm{~d}$.

\section{Total bacterial populations}

Ten gram of sample was aseptically prepared, placed in a sterile bag $(10 \times 15 \mathrm{~cm}$; Sunkyung Co., Ltd., Seoul, Korea) with $100 \mathrm{~mL}$ of peptone water $(0.1 \%)$ and pummeled in a stomacher (Model 400, Tekmar Co., LA, USA) for $1 \mathrm{~min}$. The stomached solution of sample was used to test the growth of the total bacterial populations in a plate count agar (Difco Laboratories, St. Louis, USA). Plates were prepared in triplicate and incubated at $37^{\circ} \mathrm{C}$ for $48 \mathrm{~h}$, and colonies on plates were manually counted.

\section{pH and volatile basic nitrogen (VBN)}

The $\mathrm{pH}$ of gum solution was measured with a $\mathrm{pH}$ meter (Orion 520A, Boston, USA).

A micro-diffusion method described by Cobb et al. (1973) was modified for the determination of VBN. One 2.0-g homogenized sample was mixed with $20 \mathrm{~mL}$ of $10 \%$ TCA (trichloroacetic acid) solution and blended for $10 \mathrm{~s}$ at low speed (Waring Blendor Model 34BL97, Waring Products Division, Dynamics Corporation of America, New Hartford, USA). The mixture was filtered (Whatman No. 2 filter paper). One milliliter of filtrate was placed in the Conway dish containing $1 \mathrm{~mL}$ saturated $\mathrm{K}_{2} \mathrm{CO}_{3}$ solution and allowed for reactioon at $37^{\circ} \mathrm{C}$ for 90 min. Boric acid solution containing indicator (methyl red and bromocresol green) was used to absorb volatile nitrogen. The solution was titrated with $0.01 \mathrm{~N} \mathrm{H}_{2} \mathrm{SO}_{4}$, and VBN value was reported as $\mathrm{mg} \%$.

\section{Hardness}

The hardness of the bulgogi samples $(1.5 \times 1.5 \times 0.5 \mathrm{~cm})$ was determined using a Texture Analyzer TA-XT2 model (TA-XT2i, Stable Micro System, England). Triplicate samples were sequentially compressed twice by $65 \%$ of the 
original height using a cylindrical plunger $(1.0 \mathrm{~cm}$ thickness). The hardness was directly measured from the deformation curve obtained for each sample.

\section{Sensory evaluation}

Sensory evaluation of the samples was conducted by 21 panels (20-40 ages, 11 males and 10 females) who were trained according to the method described by Ahn et al. (2000). Sensory scores of samples were referred to using a 7 point descriptive scale where $1=$ extremely dislike or extremely weak to $7=$ extremely like or extremely strong. After irradiation, samples were removed from pouches and reheated in a cooker (NU-VU ES-3 cooker, Menominee, USA) at $130^{\circ} \mathrm{C}$ for $10 \mathrm{~min}$ for sensory evaluation. The samples were cooled to $45-55^{\circ} \mathrm{C}$ at room temperature, cut into 2-cm cubes, and served to panels. Samples were served randomly to each panel $15 \mathrm{~min}$ after the packages were opened.

\section{Statistical analysis}

Samples were analyzed in triplicate and the results were presented as mean $\pm \mathrm{SD}$. All data were analyzed by the general linear model procedures of the $\mathrm{SAS}^{\circledR} 9.2$ (SAS Institute, Cary, NC, USA). Tukey's multiple range tests were used to compare least squared means among treatments at $\alpha=0.05$.

\section{Results and Discussion}

\section{Total bacterial populations}

The growth of total bacterial populations in bulgogi during storage at $35^{\circ} \mathrm{C}$ is shown in Table 2 . On $\mathrm{d} 0$, the viable cells in control were about $3 \log \mathrm{CFU} / \mathrm{g}$, and no growths of bacterial cells were observed $(p<0.05)$ on the samples treated by AC, GR, and EB at more than $5 \mathrm{kGy}$. The GR and EB (up to $10 \mathrm{kGy}$ ) treatments of the bulgogi samples were not able to sterilize viable cells in samples during storage periods. However, the bacterial populations were below detection limit $(1 \log \mathrm{CFU} / \mathrm{g})$ on the samples treated by AC, GR, and EB (more than $15 \mathrm{kGy}$ ) during storage for $90 \mathrm{~d}$. The GR treatment generally decreased $(p<0.05)$ more viable cells than EB treatment. Chung et al. (2000), Kim et al. (1998), and Park et al. (2010) also showed that GR treatment was more effective than EB treatment on the destruction of Pseudomonas fluorescens and total aerobic bacterial cells in refrigerated beef and beef sausage patties. From the present study, the shelf-stability of bulgogi could be ensured by treatments of AT, GR, and EB at more than $15 \mathrm{kGy}$.

\section{pH and VBN}

On $\mathrm{d} 0$, the $\mathrm{pH}$ of the bulgogi samples was not affected by each sterilizing treatment (Table 3). However, the $\mathrm{pH}$ of control, GR and EB (up to $10 \mathrm{kGy}$ )-treated samples was decreased $(p<0.05)$ during storage periods, and the $\mathrm{pH}$ decrement of control sample was the highest among samples. The $\mathrm{pH}$ of meat can be influenced by the presence of bacteria and may reflect the relative differentiation between the presence of Gram positive or Gram negative bacteria (Rico et al., 2009). Organic acids, produced by Gram positive bacteria, decrease the $\mathrm{pH}$ of meat, whereas amines produced by Gram negative bacte-

Table 2. Total bacterial populations (mean $\pm \mathrm{SD} ; \log \mathrm{CFU} / \mathrm{g}$ ) in bulgogi treated with various sterilizing methods during storage at $35^{\circ} \mathrm{C}$

\begin{tabular}{|c|c|c|c|c|c|}
\hline \multirow{2}{*}{ Treatment } & \multirow{2}{*}{ Dose (kGy) } & \multicolumn{4}{|c|}{ Storage (d) } \\
\hline & & 0 & 30 & 60 & 90 \\
\hline Control & 0 & $3.15 \pm 0.04^{\mathrm{aB}}$ & $8.47 \pm 0.06^{\mathrm{aA}}$ & $-1)$ & - \\
\hline $\mathrm{AC}$ & 0 & $<1 \log ^{\mathrm{bA}}$ & $<1 \log ^{\mathrm{dA}}$ & $<1 \log ^{\mathrm{cA}}$ & $<1 \log ^{\mathrm{dA}}$ \\
\hline \multirow{4}{*}{ GR } & 5 & $<1 \log ^{b D}$ & $3.41 \pm 0.02^{\mathrm{cC}}$ & $5.18 \pm 0.04^{\mathrm{aB}}$ & $7.42 \pm 0.04^{\mathrm{aA}}$ \\
\hline & 10 & $<1 \log ^{\mathrm{bC}}$ & $<1 \log ^{\mathrm{dC}}$ & $2.59 \pm 0.02^{\mathrm{bB}}$ & $4.13 \pm 0.03^{\mathrm{cA}}$ \\
\hline & 15 & $<1 \log ^{\mathrm{bA}}$ & $<1 \log ^{\mathrm{dA}}$ & $<1 \log ^{\mathrm{cA}}$ & $<1 \log ^{\mathrm{dA}}$ \\
\hline & 20 & $<1 \log ^{\mathrm{bA}}$ & $<1 \log ^{\mathrm{d} A}$ & $<1 \log ^{\mathrm{cA}}$ & $<1 \log ^{\mathrm{dA}}$ \\
\hline \multirow{4}{*}{ EB } & 5 & $<1 \log ^{\mathrm{bD}}$ & $3.53 \pm 0.03^{\mathrm{bC}}$ & $5.24 \pm 0.02^{\mathrm{aB}}$ & $7.43 \pm 0.06^{\mathrm{aA}}$ \\
\hline & 10 & $<1 \log ^{\mathrm{bC}}$ & $<1 \log ^{\mathrm{dC}}$ & $2.62 \pm 0.01^{\mathrm{bB}}$ & $4.19 \pm 0.02^{\mathrm{bA}}$ \\
\hline & 15 & $<1 \log ^{\mathrm{bA}}$ & $<1 \log ^{\mathrm{dA}}$ & $<1 \log ^{\mathrm{cA}}$ & $<1 \log ^{\mathrm{dA}}$ \\
\hline & 20 & $<1 \log ^{\mathrm{bA}}$ & $<1 \log ^{\mathrm{dA}}$ & $<1 \log ^{\mathrm{cA}}$ & $<1 \log ^{\mathrm{dA}}$ \\
\hline
\end{tabular}

\footnotetext{
${ }^{\mathrm{a}-\mathrm{d}}$ Means within the same column with different letters were significantly different $(p<0.05)$.

${ }^{A-D}$ Means within the same row with different letters were significantly different $(p<0.05)$.

${ }^{1)}$ Bar indicates no determination of total bacterial populations because of spoilage.

Abbreviation: $\mathrm{AC}$, autoclave at $121^{\circ} \mathrm{C}$ for $15 \mathrm{~min}$; GR, gamma irradiation; $\mathrm{EB}$, electron beam irradiation.
} 
Table 3. The $\mathrm{pH}$ values (mean $\pm \mathrm{SD}$ ) of $b u l g o g i$ treated with various sterilizing methods during storage at $35^{\circ} \mathrm{C}$

\begin{tabular}{cccccc}
\hline \hline \multirow{2}{*}{ Treatment } & Dose $(k G y)$ & \multicolumn{4}{c}{ Storage $(\mathrm{d})$} \\
\cline { 3 - 6 } & & 0 & 30 & 60 & 90 \\
\hline Control & 0 & $5.53 \pm 0.03^{\mathrm{aA}}$ & $4.74 \pm 0.02^{\mathrm{cB}}$ & $-^{1)}$ & - \\
\hline AC & 5 & $5.59 \pm 0.03^{\mathrm{aA}}$ & $5.53 \pm 0.04^{\mathrm{aAB}}$ & $5.45 \pm 0.05^{\mathrm{aB}}$ & $5.43 \pm 0.05^{\mathrm{aB}}$ \\
\hline & 10 & $5.58 \pm 0.05^{\mathrm{aA}}$ & $5.32 \pm 0.03^{\mathrm{bB}}$ & $5.14 \pm 0.03^{\mathrm{cC}}$ & $4.95 \pm 0.02^{\mathrm{cD}}$ \\
GR & 15 & $5.54 \pm 0.03^{\mathrm{aA}}$ & $5.52 \pm 0.04^{\mathrm{aA}}$ & $5.39 \pm 0.04^{\mathrm{bB}}$ & $5.23 \pm 0.05^{\mathrm{bC}}$ \\
& 20 & $5.57 \pm 0.02^{\mathrm{aA}}$ & $5.54 \pm 0.03^{\mathrm{aA}}$ & $5.52 \pm 0.03^{\mathrm{aAB}}$ & $5.46 \pm 0.05^{\mathrm{aB}}$ \\
& 5 & $5.56 \pm 0.02^{\mathrm{aA}}$ & $5.58 \pm 0.02^{\mathrm{aA}}$ & $5.51 \pm 0.05^{\mathrm{aAB}}$ & $5.48 \pm 0.04^{\mathrm{aB}}$ \\
\hline & 10 & $5.56 \pm 0.03^{\mathrm{aA}}$ & $5.27 \pm 0.04^{\mathrm{bB}}$ & $5.08 \pm 0.05^{\mathrm{cC}}$ & $4.91 \pm 0.03^{\mathrm{cD}}$ \\
& 15 & $5.59 \pm 0.04^{\mathrm{aA}}$ & $5.54 \pm 0.05^{\mathrm{aA}}$ & $5.35 \pm 0.04^{\mathrm{bB}}$ & $5.18 \pm 0.05^{\mathrm{bC}}$ \\
& 20 & $5.53 \pm 0.05^{\mathrm{aA}}$ & $5.51 \pm 0.03^{\mathrm{aA}}$ & $5.49 \pm 0.03^{\mathrm{aAB}}$ & $5.42 \pm 0.05^{\mathrm{aB}}$ \\
& $5.59 \pm 0.04^{\mathrm{aA}}$ & $5.54 \pm 0.05^{\mathrm{aA}}$ & $5.51 \pm 0.04^{\mathrm{aAB}}$ & $5.47 \pm 0.03^{\mathrm{aB}}$ \\
\hline
\end{tabular}

${ }^{\mathrm{a}-\mathrm{c}}$ Means within the same column with different letters were significantly different $(p<0.05)$.

${ }^{A-D}$ Means within the same row with different letters were significantly different $(p<0.05)$.

${ }^{1)} \mathrm{Bar}$ indicates no determination of $\mathrm{pH}$ because of spoilage.

Abbreviation: AC, autoclave at $121^{\circ} \mathrm{C}$ for $15 \mathrm{~min}$; GR, gamma irradiation; EB, electron beam irradiation.

ria increase $\mathrm{pH}$ (Lefebvre et al., 1994). Wong and Kitts (2002) also reported that the significant decrease in $\mathrm{pH}$ of non-irradiated samples could be explained by the preferential proliferation of Gram positive psychrotrophic bacteria.

Decomposition of protein increased amounts of VBN during storage. Thus, VBN can be an index of meat product freshness (Jay, 1992). On d 0, the samples treated with $\mathrm{AC}, \mathrm{GR}$ and $\mathrm{EB}$ had no significant differences on their VBN contents (Table 4). However, VBN contents of all treatments increased $(p<0.05)$ during storage periods, and a control, GR, and EB (up to $10 \mathrm{kGy}$ ) treated samples had higher $(p<0.05)$ VBN contents than samples treated with $\mathrm{AC}$, GR, and EB (at more than $15 \mathrm{kGy}$ ). Especially, non-treated samples remained at a higher VBN contents suggesting higher bacterial populations, which is in agreement with previous studies (Lin and Lin, 2002; Liu et al., 2010). Meanwhile, Taguchi et al. (1982) reported that increase of VBN contents in canned mackerel during long-term storage was gradually advanced despite absence of proteinase and bacterial populations because the proteins were slowly degraded during storage at room temperature.

\section{Hardness}

The hardness of the bulgogi treated with various sterilizing methods was different (Table 5). On d 0 , the hardness of all samples was decreased by sterilizing treatments, especially the hardness decrement of AC-treated sample was higher $(p<0.05)$ compared to GR and EB-

Table 4. Volatile basic nitrogen (mean $\pm \mathrm{SD} ; \mathbf{m g} \%$ ) of bulgogi treated with various sterilizing methods during storage at $35^{\circ} \mathrm{C}$

\begin{tabular}{cccccc}
\hline \hline \multirow{2}{*}{ Treatment } & Dose $(k G y)$ & \multicolumn{4}{c}{ Storage $(\mathrm{d})$} \\
\cline { 3 - 6 } & & 0 & 30 & 60 & 90 \\
\hline Control & 0 & $8.1 \pm 0.2^{\mathrm{aB}}$ & $12.4 \pm 0.6^{\mathrm{aA}}$ & $-^{1)}$ & - \\
\hline AC & 0 & $7.5 \pm 0.4^{\mathrm{aA}}$ & $7.9 \pm 0.5^{\mathrm{bA}}$ & $8.3 \pm 0.5^{\mathrm{bA}}$ & $8.2 \pm 0.4^{\mathrm{cA}}$ \\
\hline & 5 & $7.7 \pm 0.4^{\mathrm{aC}}$ & $8.2 \pm 0.3^{\mathrm{bC}}$ & $9.5 \pm 0.4^{\mathrm{aB}}$ & $10.9 \pm 0.4^{\mathrm{aA}}$ \\
GR & 10 & $7.8 \pm 0.2^{\mathrm{aB}}$ & $7.6 \pm 0.5^{\mathrm{bB}}$ & $8.4 \pm 0.5^{\mathrm{bB}}$ & $9.1 \pm 0.3^{\mathrm{bcA}}$ \\
& 15 & $7.5 \pm 0.4^{\mathrm{aA}}$ & $7.5 \pm 0.5^{\mathrm{bA}}$ & $8.2 \pm 0.4^{\mathrm{bA}}$ & $8.3 \pm 0.5^{\mathrm{cA}}$ \\
& 20 & $7.6 \pm 0.3^{\mathrm{aA}}$ & $7.8 \pm 0.4^{\mathrm{bA}}$ & $7.6 \pm 0.5^{\mathrm{bA}}$ & $7.9 \pm 0.3^{\mathrm{dA}}$ \\
\hline & 5 & $7.4 \pm 0.5^{\mathrm{aD}}$ & $8.5 \pm 0.5^{\mathrm{bC}}$ & $9.8 \pm 0.3^{\mathrm{aB}}$ & $11.4 \pm 0.6^{\mathrm{aA}}$ \\
EB & 10 & $7.6 \pm 0.4^{\mathrm{aB}}$ & $7.7 \pm 0.3^{\mathrm{bB}}$ & $8.5 \pm 0.5^{\mathrm{bB}}$ & $9.3 \pm 0.4^{\mathrm{bA}}$ \\
& 15 & $7.8 \pm 0.3^{\mathrm{aA}}$ & $7.6 \pm 0.5^{\mathrm{bA}}$ & $8.4 \pm 0.5^{\mathrm{bA}}$ & $8.2 \pm 0.4^{\mathrm{cdA}}$ \\
& 20 & $7.5 \pm 0.5^{\mathrm{aA}}$ & $7.9 \pm 0.4^{\mathrm{bA}}$ & $8.1 \pm 0.6^{\mathrm{bA}}$ & $8.4 \pm 0.5^{\mathrm{cA}}$ \\
\hline
\end{tabular}

\footnotetext{
${ }^{\mathrm{a}-\mathrm{d}}$ Means within the same column with different letters were significantly different $(p<0.05)$.

${ }^{A-D}$ Means within the same row with different letters were significantly different $(p<0.05)$.

${ }^{1)}$ Bar indicates no determination of VBN because of spoilage.

Abbreviation: $\mathrm{AC}$, autoclave at $121^{\circ} \mathrm{C}$ for $15 \mathrm{~min}$; GR, gamma irradiation; EB, electron beam irradiation.
} 
treated samples. The hardness of all samples decreased during storage periods, and the hardness of AC-treated sample was the lowest $(p<0.05)$ when compared to GR or EB treated samples after 90 d. Lee et al. (1983) showed that hardness $(\mathrm{kg})$ of canned oyster products decreased during storage at room temperature for $120 \mathrm{~d}$, and Cho et al. (1996) also reported that changes in textural characteristics (cohesiveness, springiness, and chewiness) of the canned ham were observed during storage at $37^{\circ} \mathrm{C}$ for 90 d. Taguchi et al. (1982) showed that proteins of canned mackerel were slowly degraded during storage at room temperature in spite of absence of proteinase and bacterial populations. Rheological property of meat products is one of the very important factors, and a good appearance, texture and flavor donate the satisfaction as a food to the consumer (Civille and Szczesniak, 1973). The bulgogi treated with AC undergone the extreme conditions such as high temperature $\left(121^{\circ} \mathrm{C}\right)$ and pressure (about $1.5 \mathrm{bar}$ ). Lee et al. (2005) was also indicated that the gamma irradiation up to $20 \mathrm{kGy}$ affected hardness, cohesiveness, springiness, chewiness, and gumminess of pork patties. Connective tissues and myofibrillar proteins in muscle are also broken down and denatured by irradiation, and the hardness of the meat is decreased (Yook et al., 2001).

Table 5. Hardness (mean \pm SD; $\mathrm{kg}$ ) of bulgogi treated with various sterilizing methods during storage at $35^{\circ} \mathrm{C}$

\begin{tabular}{cccccc}
\hline \hline \multirow{2}{*}{ Treatment } & Dose $(k G y)$ & \multicolumn{4}{c}{ Storage $(\mathrm{d})$} \\
\cline { 3 - 6 } & & 0 & 30 & 60 & 90 \\
\hline Control & 0 & $1.33 \pm 0.09^{\mathrm{aA}}$ & $1.03 \pm 0.08^{\mathrm{aB}}$ & $-^{1)}$ & - \\
\hline AC & 0 & $0.71 \pm 0.06^{\mathrm{eA}}$ & $0.57 \pm 0.03^{\mathrm{dB}}$ & $0.42 \pm 0.04^{\mathrm{cC}}$ & $0.36 \pm 0.03^{\mathrm{cD}}$ \\
\hline & 5 & $1.18 \pm 0.03^{\mathrm{bA}}$ & $0.91 \pm 0.05^{\mathrm{aB}}$ & $0.73 \pm 0.05^{\mathrm{aC}}$ & $0.58 \pm 0.03^{\mathrm{aD}}$ \\
GR & 10 & $0.99 \pm 0.06^{\mathrm{cA}}$ & $0.76 \pm 0.05^{\mathrm{bB}}$ & $0.54 \pm 0.07^{\mathrm{bC}}$ & $0.51 \pm 0.04^{\mathrm{abC}}$ \\
& 15 & $0.92 \pm 0.04^{\mathrm{cA}}$ & $0.68 \pm 0.06^{\mathrm{cB}}$ & $0.51 \pm 0.05^{\mathrm{bCC}}$ & $0.46 \pm 0.05^{\mathrm{bC}}$ \\
& 20 & $0.84 \pm 0.06^{\mathrm{dA}}$ & $0.64 \pm 0.04^{\mathrm{cdB}}$ & $0.47 \pm 0.05^{\mathrm{cC}}$ & $0.42 \pm 0.04^{\mathrm{bcC}}$ \\
\hline & 5 & $1.19 \pm 0.06^{\mathrm{abA}}$ & $0.95 \pm 0.05^{\mathrm{aB}}$ & $0.76 \pm 0.03^{\mathrm{aC}}$ & $0.57 \pm 0.05^{\mathrm{aD}}$ \\
& 10 & $1.02 \pm 0.08^{\mathrm{cA}}$ & $0.78 \pm 0.05^{\mathrm{bB}}$ & $0.57 \pm 0.03^{\mathrm{bC}}$ & $0.52 \pm 0.04^{\mathrm{aC}}$ \\
& 15 & $0.95 \pm 0.05^{\mathrm{cA}}$ & $0.69 \pm 0.04^{\mathrm{bcB}}$ & $0.52 \pm 0.05^{\mathrm{bC}}$ & $0.48 \pm 0.04^{\mathrm{bC}}$ \\
& 20 & $0.86 \pm 0.07^{\mathrm{cdA}}$ & $0.66 \pm 0.06^{\mathrm{cB}}$ & $0.49 \pm 0.04^{\mathrm{cC}}$ & $0.45 \pm 0.05^{\mathrm{bC}}$ \\
\hline
\end{tabular}

${ }^{\mathrm{a}-\mathrm{e}}$ Means within the same column with different letters were significantly different $(p<0.05)$.

${ }^{A-D}$ Means within the same row with different letters were significantly different $(p<0.05)$.

${ }^{1)}$ Bar indicates no determination of hardness because of spoilage.

Abbreviation: $\mathrm{AC}$, autoclave at $121^{\circ} \mathrm{C}$ for $15 \mathrm{~min}$; GR, gamma irradiation; EB, electron beam irradiation.

Table 6. Sensory properties of bulgogi treated with various sterilizing methods during storage at $35^{\circ} \mathrm{C}$

\begin{tabular}{|c|c|c|c|c|c|c|c|}
\hline Days & Treatment & Dose (kGy) & Color & Texture & Taste & Flavor & $\begin{array}{c}\text { Overall } \\
\text { acceptance }\end{array}$ \\
\hline \multirow{10}{*}{0} & Control & 0 & $6.8 \pm 0.5^{\mathrm{a}}$ & $6.5 \pm 0.6^{\mathrm{a}}$ & $6.9 \pm 0.5^{\mathrm{a}}$ & $6.8 \pm 0.6^{\mathrm{a}}$ & $6.9 \pm 0.6^{\mathrm{a}}$ \\
\hline & $\mathrm{AC}$ & 0 & $5.1 \pm 0.6^{\mathrm{bc}}$ & $3.2 \pm 0.3^{\mathrm{b}}$ & $3.8 \pm 0.3^{\mathrm{d}}$ & $4.9 \pm 0.5^{\mathrm{c}}$ & $3.8 \pm 0.4^{\mathrm{d}}$ \\
\hline & \multirow{4}{*}{ GR } & 5 & $6.4 \pm 0.5^{\mathrm{a}}$ & $6.3 \pm 0.6^{\mathrm{a}}$ & $6.4 \pm 0.5^{\mathrm{a}}$ & $6.6 \pm 0.5^{\mathrm{a}}$ & $6.5 \pm 0.7^{\mathrm{a}}$ \\
\hline & & 10 & $5.6 \pm 0.4^{b}$ & $6.4 \pm 0.5^{\mathrm{a}}$ & $5.6 \pm 0.3^{b}$ & $5.8 \pm 0.6^{\mathrm{ab}}$ & $5.6 \pm 0.5^{b}$ \\
\hline & & 15 & $5.3 \pm 0.6^{\mathrm{b}}$ & $6.7 \pm 0.5^{\mathrm{a}}$ & $5.3 \pm 0.4^{\mathrm{b}}$ & $5.7 \pm 0.4^{\mathrm{b}}$ & $5.4 \pm 0.5^{\mathrm{b}}$ \\
\hline & & 20 & $5.4 \pm 0.5^{\mathrm{b}}$ & $6.6 \pm 0.4^{\mathrm{a}}$ & $5.1 \pm 0.5^{\mathrm{bc}}$ & $5.4 \pm 0.3^{\mathrm{bc}}$ & $5.1 \pm 0.5^{\mathrm{bc}}$ \\
\hline & \multirow{4}{*}{ EB } & 5 & $6.7 \pm 0.7^{\mathrm{a}}$ & $6.5 \pm 0.5^{\mathrm{a}}$ & $6.8 \pm 0.6^{\mathrm{a}}$ & $6.7 \pm 0.5^{\mathrm{a}}$ & $6.7 \pm 0.6^{\mathrm{a}}$ \\
\hline & & 10 & $6.1 \pm 0.6^{\mathrm{ab}}$ & $6.3 \pm 0.5^{\mathrm{a}}$ & $5.9 \pm 0.5^{\mathrm{ab}}$ & $6.1 \pm 0.4^{\mathrm{a}}$ & $5.9 \pm 0.5^{\mathrm{ab}}$ \\
\hline & & 15 & $5.8 \pm 0.4^{\mathrm{b}}$ & $6.1 \pm 0.7^{\mathrm{a}}$ & $5.6 \pm 0.5^{\mathrm{b}}$ & $5.9 \pm 0.5^{\mathrm{a}}$ & $5.5 \pm 0.4^{b}$ \\
\hline & & 20 & $5.6 \pm 0.5^{\mathrm{b}}$ & $6.7 \pm 0.6^{\mathrm{a}}$ & $5.5 \pm 0.5^{\mathrm{b}}$ & $5.6 \pm 0.3^{\mathrm{b}}$ & $5.4 \pm 0.6^{\mathrm{b}}$ \\
\hline \multirow{5}{*}{90} & $\mathrm{AC}$ & 0 & $3.6 \pm 0.3^{\mathrm{d}}$ & $2.1 \pm 0.3^{\mathrm{c}}$ & $3.1 \pm 0.2^{\mathrm{e}}$ & $3.5 \pm 0.4^{\mathrm{d}}$ & $2.9 \pm 0.2^{\mathrm{e}}$ \\
\hline & \multirow{2}{*}{ GR } & 15 & $4.3 \pm 0.4^{\text {cd }}$ & $5.7 \pm 0.5^{\mathrm{a}}$ & $4.2 \pm 0.5^{\text {cd }}$ & $4.3 \pm 0.3^{\mathrm{c}}$ & $4.2 \pm 0.5^{\mathrm{cd}}$ \\
\hline & & 20 & $4.1 \pm 0.3^{\mathrm{d}}$ & $6.3 \pm 0.6^{\mathrm{a}}$ & $3.9 \pm 0.3^{\mathrm{d}}$ & $4.1 \pm 0.5^{\mathrm{cd}}$ & $3.8 \pm 0.4^{\mathrm{d}}$ \\
\hline & \multirow{2}{*}{ EB } & 15 & $4.7 \pm 0.3^{\mathrm{c}}$ & $5.9 \pm 0.5^{\mathrm{a}}$ & $4.4 \pm 0.5^{\mathrm{c}}$ & $4.5 \pm 0.3^{\mathrm{c}}$ & $4.3 \pm 0.4^{\mathrm{c}}$ \\
\hline & & 20 & $4.3 \pm 0.5^{\mathrm{cd}}$ & $6.2 \pm 0.7^{\mathrm{a}}$ & $4.2 \pm 0.5^{\mathrm{cd}}$ & $4.4 \pm 0.5^{\mathrm{c}}$ & $4.1 \pm 0.3^{\mathrm{d}}$ \\
\hline
\end{tabular}

${ }^{a-e}$ Means within the same column with different letters were significantly different $(p<0.05)$.

Abbreviation: AC, autoclave at $121^{\circ} \mathrm{C}$ for $15 \mathrm{~min}$; GR, gamma irradiation; EB, electron beam irradiation. 
Meanwhile, Park et al. (2010) reported that the hardness of beef sausage patties irradiated by gamma ray or electron beam was not significantly different.

\section{Sensory properties}

On d 0, the control, GR or EB-treated samples showed the high scores for all sensory properties (color, texture, taste and flavor), and the properties were similar among treatments (Table 6). However, the sensory qualities (texture and taste) of AC-treated sample had the lowest ( $p<$ $0.05)$ scores in all samples. AC treatment at $121^{\circ} \mathrm{C}$ for 15 min extremely compromised the texture and taste of bulgogi sample. Briefly, the AC-treated sample had greasy appearance, brittle texture, oily taste and flavor, because fat of bulgogi was excessively melted by high temperature, and the texture was collapsed by high pressure (about 1.5 bar). Generally, the heat treatment may adversely affect flavor, taste and texture of the vegetables and meat because of losing freshness, resulting in decreased consumers' acceptance (Jo et al., 2003b). The sensory properties (color, texture, taste and flavor) of AC, GR and EB (15 and $20 \mathrm{kGy}$ )-treated samples were also decreased during storage at $35^{\circ} \mathrm{C}$, especially the sensory qualities (texture and taste) of AC-treated samples were most deteriorated in samples. Even though the sensory quality of irradiated samples was superior to AC-treated sample, irradiation induced adverse effect such as off-flavor. Most chemical changes such as off-flavor generation in meat are associated with free radical reactions (Smith et al., 1960). Irradiation can initiate or promote lipid oxidation, resulting in undesirable off-odors and flavors (Tappel et al., 1958). However, the generation of off-flavor in irradiated meat and meat products could be reduced by various methods such as modified atmosphere packaging, low irradiation temperature (freezing), and addition of antioxidants (Brewer, 2009).

\section{Conclusions}

The treatments of $\mathrm{AC}\left(121^{\circ} \mathrm{C}, 15 \mathrm{~min}\right), \mathrm{GR}$, and $\mathrm{EB}(15$ $\mathrm{kGy}$ ) could be used to ensure the microbial safety of bulgogi during storage at $35^{\circ} \mathrm{C}$ for $90 \mathrm{~d}$. However, the adverse effects (tenderization and deterioration of sensory quality) were induced by sterilizing treatments, especially the AC treatment extremely deteriorated $(p<0.05)$ the appearance, texture, and taste of bulgogi sample. Meanwhile, the further studies on combined treatments such as low irradiation temperature (freezing) and addition of antioxidants are needed to decrease adverse effect (ten- derization and off-flavor induction) induced by high-dose irradiation.

\section{Acknowledgements}

This research was co-supported by the National Research Foundation in the Nuclear Research \& Development Program, and by the Basic Research Support Program of Korea Atomic Energy Research Institute.

\section{References}

1. Ahn, D. U., Jo, C., and Olson, D. G. (2000) Analysis of volatile components and the sensory characteristics of irradiated raw pork. Meat Sci. 54, 209-215.

2. Beuchat, L. R. (1996) Pathogenic microorganisms associated with fresh produce. J. Food Prot. 59, 204-216.

3. Brewer, M. S. (2009) Irradiation effects on meat flavor: a review. Meat Sci. 81, 1-14.

4. Cho, Y. B., Kim, S. H., Lim, J. Y., and Han, B. H. (1996) Optimal sterilizing condition for canned ham. J. Korean Soc. Food Nutr. 25, 301-309.

5. Chung, M. S., Ko, Y. T., and Kim, W. S. (2000) Survival of Pseudomonas fluorescens and Salmonella Typhimurium after electron beam and gamma irradiation of refrigerated beef. J. Food Prot. 63, 162-166.

6. Civille, G. V. and Szczesniak, A. S. (1973) Guidelines to training a texture profile panel. J. Texture Stud. 4, 204-223.

7. Cobb, B. F., Alaniz, I., and Thompson, C. A. (1973) Biochemical and microbial studies on shrimp: Volatile nitrogen and amino analysis. J. Food Sci. 38, 431-436.

8. Jay, J. M. (1992) Modern food microbiology. New York: Chapman and Hall.

9. Jo, C., Han, C. D., Chung, K. H., and Byun, M. W. (2003a) Gamma irradiation of ready-to-cook Bulgogi improves safety and extends shelf-life without compromising organoleptic qualities. Nutraceuticals and Food, 8, 191-195.

10. Jo, C., Kim, D. H., Shin, M. G., Kang, I. J., and Byun, M. W. (2003b) Irradiation effect on bulgogi sauce for making commercial Korean traditional meat product, bulgogi. Radiat. Phy. Chem. 68. 851-856.

11. Kim, W. S., Chung, M. S., and Ko, Y, T. (1998) Effects of low dose gamma ray and electron beam irradiation on growth of microorganisms in beef during the refrigerated storage. Korean J. Food Sci. Ani. Resour. 18, 232-239.

12. Lee, E. H., Cho, S. Y., Chung, S. Y., and Cha, Y. J. (1983) Preparation and keeping quality of canned liquid smoked oyster products. Bull. Korean Fish. Soc. 16, 1-7.

13. Lee, J. W., Park, K. S., Kim, J. G., Oh, S. H., Lee, Y. S., Kim, J. H., and Byun, M. W. (2005) Combined effects of gamma irradiation and rosemary extract on the shelf-life of a readyto-eat hamburger steak. Radiat. Phy. Chem. 72, 49-56.

14. Lee, Y. C., Kim, S. H., and Oh, S. S. (2001) Effect of gamma irradiation on the quality of Bulgogi sauce. Korean J. Food 
Sci. Technol. 33, 327-332.

15. Lefebvre, N., Thibault, C., Charbonneau, R., and Piette, J. P. G. (1994) Improvement of shelf-life by irradiation -2: chemical analysis and sensory evaluation. Meat Sci. 36, 377-380.

16. Lin, K. W. and Lin, S. N. (2002) Effects of sodium lactate and trisodium phosphate on the physicochemical properties and shelf life of low-fat Chinese-style sausage. Meat Sci. 60, 147-154.

17. Liu, D. C., Wu, S. W., and Tan, F. J. (2010) Effects of addition of anka rice on the qualities of low-nitrite Chinese sausages. Food Chem. 118, 245-250.

18. Nguyen-the, C. and Carlin, F. (1994) The microbiology of minimally processed fresh fruits and vegetables. Crit. Rev. Food Sci. Nutr. 34, 370-401.

19. Park, J. G., Her, J. H., Li, S. Y., Cho, S. H., Youn, S. K., Choi, J. S., Park, S. M., and Ahn, D. H. (2005) Study on the improvement of storage property and quality in the traditional seasoning beef containing medicinal herb extracts. $J$. Korean Soc. Food Sci. Nutr. 34, 113-119.

20. Park, J. G., Yoon, Y., Park, J. N., Han, I. J., Song, B. S., Kim, J. H., Kim, W. G., Hwang, H. J., Han, S. B., and Lee, J. W. (2010) Effect of gamma irradiation and electron beam irradiation on quality, sensory, and bacterial populations in beef sausage patties. Meat Sci. 85, 368-372.

21. Rico, C. W., Kim, G. R., J, C., Nam, K. C., Kang, H. J., Ahn, D. U., and Kwon, J. H. (2009) Microbiological and physicochemical quality of irradiated ground beef as affected by added garlic or onion. Korean J. Food Sci. Ani. Resour. 29, 680-684.

22. Smith, N. L., Tinsley, I. J., and Bubl, C. E. (1960) The thiobarbituric acid test in irradiation sterilized beef. Food Technol. 14, 317-320.

23. Song, T. H., Kim, D. H., Park, B. J., Shin, M. G., and Byun, M. W. (2001) Changes in microbiological and general quality characteristics of gamma irradiated Kanjang and Shoyu. J. Korean Soc. Food Sci. Technol. 33, 338-344.

24. Taguchi, T., Tanaka, M., Okubo, S., and Suzuki, K. (1982) Changes in quality of canned mackerel during long-term storage. Bull. Jap. Soc. Sci. Fish. 48, 1765-1769.

25. Tappel, A. L., Groninger, H., and Knapp, F. W. (1958) Relationship of irradiation induced fat oxidation and flavor, color and vitamin changes in meat. Quartermaster Food and Container Institute for the Armed Forces. Natick, MS.

26. Wong, P. Y. Y. and Kitts, D. D. (2002) The effects of herbal pre-seasoning on microbial and oxidative changes in irradiated beef steaks. Food Chem. 76, 197-205.

27. Yook, H. S., Lee, J. W., Lee, K. H., Kim, M. K., Song, C. W., and Byun, M. W. (2001) Effect of gamma irradiation on the microstructure and post-mortem anaerobic metabolism of bovine muscle. Radiat. Phys. Chem. 61, 163-169.

28. World Health Organization. (1999) High-dose irradiation: Wholesomeness of food irradiated with dose above $10 \mathrm{kGy}$. WHO Technical Report Series 890. Geneva.

$\overline{\text { (Received 2010.9.1/Revised 2010.10.13/Accepted 2010.10.14) }}$ 